\title{
ESP SPEAKING STRATEGIES AND FOREIGN LANGUAGE ANXIETY IN HIGHER EDUCATION CLASSROOM**
}

The study examines the undergraduate students' perceived use of foreign language speaking strategies, their levels of foreign language anxiety, and the potential relationships between them. Two instruments were used in the study - Inventory of Speaking Strategies in a Foreign Language, based on the instrument Strategy Inventory in Foreign Language Learning, and Foreign Language Classroom Anxiety Scale. The results showed that students' overall perceived use of speaking strategies in English as a foreign language for specific purposes was frequent. The findings also revealed that the students' foreign language anxiety was at a medium level; individual performance anxieties remained at the same medium levels. A few differences were found between the low-anxious and highanxious groups on the speaking strategy use: the former uses circumlocutions and synonyms when stuck with a word in English more frequently while the latter is paying attention more often when someone is speaking in English. The results also suggest that the mediumanxious group uses gestures when unable to think of a word during a conversation in English less frequently than the low-anxious group.

Keywords: anxiety, English for specific purposes, foreign language, speaking, strategies

\section{INTRODUCTION}

Since the 1970s, many researchers and practitioners in the field of foreign language learning/second language acquisition have been aware of the importance of using language learning strategies to achieve command over foreign language skills

\footnotetext{
*milevicabojovic@gmail.com

** The paper was presented at ELALT 5 Conference held in March 2019 at the Faculty of Philosophy, University of Novi Sad. The sample was used for the paper written by the author and published in the Book of Proceedings "Selected papers from the Third International Conference English Language and Anglophone Literatures Today (ELALT 3) in 2017 , pp. 207-224.
} 
(Rubin, 1975; Stern, 1975; O’Malley-Chamot-Stewner-Manzanares-Russo, \& Kupper, 1985: 557). Language learning strategies, in addition to intelligence, aptitude, and learning styles, are cognitive factors that can be the root cause of a student's inability to reach the desired level of foreign language proficiency. Using the skill-based approach, language learning strategies are viewed in terms of their role in the receptive skills of listening and reading, as well as the productive skills of speaking and writing (Oxford, 1990; Cohen, 2010). Speaking strategies, which are viewed as the means used to operationalize speaking skills (Cohen, 2014), are assumed to improve foreign language proficiency substantially and spoken performance in particular. The affective variables, such as beliefs and attitudes, anxiety, interests, motivation, and inhibition, have also been recognized as one set of critical factors used to explain varying degrees of success among foreign language learners (Samimy, 1994: 29-30).

Many learners are eager to learn a new language, and yet, they consider it a challenging task and often describe and consider it an uncomfortable experience. Hence, researchers have shifted the focus on learners' emotional responses to learning a foreign language and their impact on classroom performance. Affective variables include language learning anxiety, which has been widely investigated over the last three decades (Horwitz, 2010). Foreign language anxiety manifests itself in a foreign language learning context where learners may experience the worry and negative emotional reaction aroused when learning a new language (MacIntyre, 1999: 27). A body of literature has suggested that a high level of foreign language anxiety interferes with foreign language learning (Horwitz-Horwitz, \& Cope, 1986; MacIntyre-Gardner, 1994; Ohata, 2005; Young, 1991), and a sentiment of worry during language activities (speaking in particular) in the classroom seems to be the commonly identified among the obstacles of foreign language fluency (Gkonou, 2014). According to Lucas, Miraflores, and Gou (2011), foreign language learners seek to equip themselves with learning strategies that help them not only to learn the target language but also to cope with their language learning anxieties.

Studies investigating the relationship between strategy use and foreign language anxiety have shown that the students who have lower levels of foreign language anxiety used language learning strategies more than those with higher levels of language anxiety (Olivares-Cuhat, 2010; Pawlak, 2011; Sioson, 2011), although other studies have suggested that foreign language anxiety has less influence on language strategies than other variables, such as students' motivation or attitudes towards the learning context (MacIntyre-Noels, 1996). 
The aim of the present study is to determine how biotechnology engineering students behave when they speak in English as a foreign language for specific purposes by examining their perceived use of speaking strategies. It also aims to investigate the potential relationships between students' levels of foreign language anxiety and their perceived use of EFL speaking strategies, or more specifically, which types of speaking strategies learners at different levels of language anxiety use. Whether students who are less or more anxious than other students use language speaking strategies more frequently is worth a closer examination. Understanding these areas may contribute to the understanding of advantages and limitations regarding the development of students' ability to learn to speak English in the context of foreign language instruction in the field of biotechnical sciences.

\section{THEORETICAL BACKGROUND}

\subsection{Language learning strategies and EFL speaking strategies}

There are many language learning strategy definitions in the literature. One of the earliest researchers in the field of foreign/second language learning, Rubin, defined foreign language learning strategies as "techniques or devices that learners apply in order to acquire knowledge of a foreign language" (Rubin, 1975: 43). Language learning strategies are also defined as "specific actions or techniques that students use, often intentionally, to improve their progress in developing foreign language skills" (Green-Oxford, 1995: 262). Language learning strategies are purposeful, situated (in a real setting) mental actions, used by learners to meet learning needs; they are sometimes observable, helping learners in developing selfregulation, completing tasks in a foreign/second language, and moving forward foreign/second language proficiency; language learning strategies are dynamic, complex, and fluid (they are not part of rigid categories or used only for certain functions), used consciously or at least partially consciously; they can be discussed in terms of functions (metastrategic, cognitive, emotional/affective, motivational, and social), and they can be taught, assessed, and researched (Oxford, 2017). The ultimate goal of language learning strategies is to promote language proficiency (Tudor, 1996) so that the learner can use the language outside the classroom.

Grouping strategies involve two notable approaches:

1. categorization according to their psychological functions into memory, cognitive, compensation, metacognitive, affective, and social strategies (Oxford, 1990); and 
2. categorization according to the skill area to which they relate, into listening and reading strategies (receptive skills), speaking and writing strategies (productive skills), vocabulary learning, and translation strategies (Cohen 2010), grammar learning strategies (Oxford, 2017; Pawlak, 2018a), strategies for learning pragmatics (speech acts) (Cohen, 2005).

In this study, speaking strategies are tools used by foreign language learners to solve any communication problems when speaking in a foreign language. They are used to practice speaking, engage in a conversation, and keep the conversation going when words or expressions are lacking. Speaking strategies help foreign language learners "in negotiating meaning where either linguistic structures or sociolinguistic rules are not shared between a foreign language learner and a speaker of the target language" (O'Malley-Chamot, 1990: 43). The concept of speaking strategies is based on a combination of language learning strategies, particularly on Oxford's language learning strategies (1990), and skill area strategies — speaking strategies.

Speaking is a highly complex skill that comprises knowledge of language and discourse, core speaking skills (e.g. chunking, signalling intention, turn-taking), and speaking strategies (Goh-Burns, 2012). Foreign language learners usually encounter difficulties in the mastery of speaking - speaking is the skill in which the students' language ego is most vulnerable due to a higher level of self-exposure that it imposes on them (Gkonou, 2014). Hence, speaking in front of the class is an in-class activity producing a high level of anxiety (Young, 1999).

\subsection{Foreign language anxiety}

Foreign language anxiety (FLA) implies "performance evaluation within an academic and social context" (Horwitz-Horwitz, \& Cope, 1986: 127). They identified three related performance anxieties: communication apprehension, test anxiety, and fear of negative evaluation, which are believed to "provide useful conceptual building blocks for a description of foreign language anxiety" (Horwitz, 1986: 128).

Communication apprehension (CA) refers to shyness, fear, and anxiety which individuals experience when they have to communicate with others; it is manifested as difficulties and discomfort in speaking (oral communication anxiety or speaking anxiety) in groups, in public, or in listening to or learning a spoken message (receiver anxiety) (Horwitz et al., 1986: 127). The usual behaviour of communicatively apprehensive people involves communication avoidance and withdrawal (Aida, 1994: 156). 
Test anxiety (TA) is the performance anxiety stemming from a fear of failure (Gordon-Sarason, 1955). Test-anxious students often have unrealistic goals, feeling that anything less than perfect test performance is a failure. Speaking in a foreign language has the potential of provoking both test and oral communication anxiety at the same time.

Fear of negative evaluation (FNE) is an individual's fear of being evaluated, distress about negative evaluation, avoidance of evaluative situations, and the expectations of being negatively evaluated (Watson-Friend, 1969: 449). It can be applied to any aspect of social and evaluative context (e.g., job interview, oral presentation in the foreign language classroom), not only to testing context.

Relatively little attention has been given to investigating speaking strategies that develop speaking skills and enhance speaking performance. Few available empirical studies suggest that the high achievers were more likely to engage in functional practice such as talking to oneself or reading to get the models for speaking (Huang-van Naerssen, 1987), adequate planning and preparation, practicing speaking daily, starting discussions with their peers and relying on stop-gap strategies when communication breakdowns occurred (Kawai, 2008), or paying attention to what their partner was saying, and self-evaluating their success on the completion of the tasks, frequent deployment of cooperation, asking for clarification or verification, circumlocution, approximation, gesticulation, reliance on the mother tongue (Pawlak, 2018b).

When speaking in a foreign language, language anxiety tends to be more debilitative than facilitative. Using speaking strategies may reduce levels of language anxiety. According to Sioson (2011), the students' use of planning and monitoring while speaking in a foreign language or goal-setting lessens their language anxiety (communication apprehension and fear of negative evaluation in particular), making them more self-confident. Also, some studies suggest that the lower anxiety the students had, the higher use of strategies they made (Khamkhien, 2012; YamashiroMcLaughlin, 2001; Wu, 2010).

\section{METHOD}

\subsection{Research questions}

The study aims to answer the following research questions:

1. Which EFL speaking strategies do the students in biotechnology engineering use, and how frequently?

2. What are the levels of foreign language anxiety among the students? 
3. Are there differences in speaking strategy use between learners manifesting different levels of foreign language anxiety?

\subsection{Participants}

The participants in this study were 60 undergraduate students of biotechnology engineering (47 females and 13 males) in a four-year bachelor program at the University of Kragujevac (sophomores, juniors, and seniors), learning English for specific purposes (ESP). According to the results obtained by the EFL placement test applied at the beginning of the semester, the students' EFL proficiency was at the $\mathrm{B} 1$ level of CEFR.

\subsection{Variables}

The variables in the study are as follows:

- foreign language speaking strategies, including memory, cognitive, compensation, metacognitive, and affective strategies;

- foreign language classroom anxiety and its performance anxieties: communication apprehension, test anxiety, and fear of negative evaluation.

\subsection{Instruments}

The research instruments involved the Inventory of Speaking Strategies in a Foreign Language (ISSFL) and Foreign Language Classroom Anxiety Scale (FLCAS) (Horwitz, 1986; Horwitz et al., 1986).

\subsubsection{Inventory of Speaking Strategies in a Foreign Language}

The ISSFL instrument is a tool for measuring the perceived use of speaking strategies by non-native English speakers. It is derived from the Strategy Inventory for Language Learning (SILL), Version 7.0, for measuring strategies for learning a foreign/second language (Oxford, 1989). This self-report, five-point Likert-type scale comprises 20 items with choices ranging from "never or almost never true of me" (1) to "always or almost always true of me" (5). The high end of the scale indicates a high frequency of speaking strategy use while the low end indicates a low frequency of use. The items were written in the participants' mother tongue (Serbian) to avoid unnecessary miscomprehension; then they were back-translated into English by an independent language expert for linguistic validation of the instrument. 


\subsubsection{Foreign Language Classroom Anxiety Scale}

The FLCAS (Horwitz, 1986; Horwitz et al., 1986) items measure foreign language learner's anxiety from the perspective of total anxiety in the foreign language, which includes communication apprehension, test anxiety, and fear of negative evaluation. The instrument was designed to measure the level of anxiety that foreign language learners experience in the language classroom. This five-point Likert-type scale comprises 33 items, ranging from "strongly agree" (1) to "strongly disagree" (5). The theoretical range of the FLCAS is from 33 to 165. The positively worded statements express low levels of anxiety, while negatively worded statements express high anxiety levels. The positively worded statements were reverse-scored, ranging from "strongly disagree" (1) to "strongly agree" (5), lower scores indicating higher levels of anxiety, and vice versa. The scale is adapted so that the items refer to learning EFL. The instrument was translated into Serbian language and translated back into English by an independent language expert for the instrument language validation.

\subsection{Procedure}

The instruments used for collecting the data in the study they were administered to the participants by their ESP teacher during their regular ESP classes. The ESP classes involved regular speaking activities aimed at the development of speaking skills. Rather than being presented as a separate learning task, speaking strategies were implicitly embedded in the classroom activities.

The measures of internal consistency, descriptive and correlation statistics were used for data processing. We analyzed the obtained data using SPSS 20.00 Package for Windows. For the Likert-scaled strategy-use items of the ISSFL, the following key helped to interpret the means: mean values from 3.5 to 5.0 indicate high use, from 2.5 to 3.49 indicate medium use, and from 1.0 to 2.49 low use (Oxford, 1990). To determine the levels of students' language anxiety, the 60 students were classified into three groups — high-anxious, medium-anxious, and low-anxious - based on their scores on FLCAS. The authors of the FLACS (Horwitz, 1986; Horwitz et al., 1986) did not include the scoring procedure with the instrument. To determine a student's foreign language anxiety level, including three performance anxieties (communication apprehension, test anxiety, and fear of negative evaluation), local norms are established for the FLACS. The students mean scores are transformed into z scores: the students scoring more than two-thirds standard deviations above the overall sample mean are identified as low-anxious; 
those between +0.67 and - .67 standard deviations from the sample mean are identified as medium-anxious; and, those scoring more than two-thirds standard deviations below the sample mean are identified as high-anxious. Two-thirds standard deviation is used as the "cut point" for the high and low anxiety groups to ensure that each group includes enough students for comparison (SparksGanschow, 2007).

\section{RESULTS}

In this study, the instrument ISSFL proved to be reliable and internally consistent since the coefficient Cronbach's alpha is 0.83 . This result is within the coefficient values found in the literature for SILL, on which the ISSFL is based, ranging from 0.81 to 0.94 (Oh, 1992; Yang, 1999; Lee-Oxford, 2008; Murray, 2010; Olivares-Cuhat, 2010; Yang, 2010; Liu-Chang, 2013). Also, the instrument FLCAS proved to be reliable and highly internally consistent since the coefficient Cronbach alpha is $r=0.93$. This result is within the values found in the literature ranging from 0.90-0.96 (Horwitz, 1986; Horwitz et al., 1986; Aida 1994; ChengHorwitz, \& Schallert, 1999; Rodriguez-Abreu, 2003; Toth, 2008; Yan-Horwitz, 2008; Tallon, 2011).

\subsection{The students' perceived use of speaking strategies in EFL}

Descriptive statistics (mean value and standard deviation) was used to describe how the biotechnology engineering students perceived their use of speaking strategies, the means of self-reported scores for the speaking strategies being shown in Table 1.

Table 1 -The use of EFL speaking strategies in biotechnology

\begin{tabular}{lcccc}
\hline \multicolumn{1}{c}{ Speaking strategies } & $\begin{array}{c}\text { Possible } \\
\text { scores }\end{array}$ & M & SD & $\begin{array}{c}\text { Rank } \\
\text { usage }\end{array}$ \\
\hline Associate new material w/already known & $1-5$ & 4.27 & .733 & frequent \\
\hline Use new English words in a sentence & $1-5$ & 3.07 & .880 & medium \\
\hline $\begin{array}{l}\text { Connect a word to a mental picture of the } \\
\text { situation }\end{array}$ & $1-5$ & 3.75 & .932 & frequent \\
\hline Use rhymes to remember new words & $1-5$ & 2.43 & 1.240 & low \\
\hline Say new words several times & $1-5$ & 3.53 & 1.157 & frequent \\
\hline Try to talk like a native speaker & $1-5$ & 3.38 & .976 & medium \\
\hline
\end{tabular}




\begin{tabular}{lcccc}
\hline Practice sounds of English & $1-5$ & 3.75 & 1.068 & frequent \\
\hline Start a conversation in English & $1-5$ & 2.67 & 1.003 & medium \\
\hline Make summaries of information & $1-5$ & 2.97 & .991 & medium \\
\hline Use gestures when stuck for words & $1-5$ & 3.65 & .777 & frequent \\
\hline Make up new words when stuck & $1-5$ & 3.47 & .965 & medium \\
\hline Try to guess what other people will say & $1-5$ & 2.88 & 1.010 & medium \\
\hline Use circumlocutions or synonyms & $1-5$ & 3.93 & .861 & frequent \\
\hline Notice my mistakes/try to do better & $1-5$ & 3.95 & .746 & frequent \\
\hline Pay attention when someone is speaking & $1-5$ & 4.42 & .645 & frequent \\
\hline Look for people to talk to in English & $1-5$ & 3.23 & .789 & medium \\
\hline $\begin{array}{l}\text { Have clear goals for improving speaking } \\
\text { skills }\end{array}$ & $1-5$ & 4.53 & .769 & frequent \\
\hline Try to relax when feeling afraid of speaking & $1-5$ & 4.18 & 1.000 & frequent \\
\hline Encourage self to speak when feeling afraid & $1-5$ & 3.97 & .974 & frequent \\
\hline Give self-reward for doing well & $1-5$ & 2.92 & 1.139 & medium \\
\hline Overall EFL speaking strategies & $1-5$ & 3.55 & .459 & frequent \\
\hline EFL Engl as a for
\end{tabular}

EFL-English as a foreign language, $\mathrm{M}$-mean value, SD-standard deviation, $\mathrm{N}$-number of participants

The mean value of the overall perceived use of speaking strategies shows the students' frequent use of EFL speaking strategies $(\mathrm{M}=3.55)$. The analysis reported eleven speaking strategies as high usage strategies. Associating new material with the material the students already know, paying attention when someone is speaking in English, having clear goals for improving speaking skills in English, and trying to relax when afraid of speaking in English are the four most frequently used speaking strategies $(\mathrm{M}=4.27, \mathrm{M}=4.42, \mathrm{M}=4.53$, and $\mathrm{M}=4.18$, respectively). The other speaking strategies at the high level of usage involve the following strategies: connecting the sounds of new words to a mental picture of a situation ( $M=3.75)$; saying new words in English several times $(M=3.53)$; practicing the sounds of English $(\mathrm{M}=3.75)$; using gestures when stuck for words when speaking in English $(\mathrm{M}=3.65)$; using circumlocutions or synonyms when stuck for an English word ( $\mathrm{M}=3.93)$; noticing mistakes and trying to do better when speaking in English ( $M=3.95)$; encouraging oneself to speak when afraid of making mistakes when speaking in English $(\mathrm{M}=3.97)$. 
Eight speaking strategies are medium usage strategies, as shown in Table 1. The least frequently used speaking strategy is using rhymes to remember new words in English, where the mean value was $\mathrm{M}=2.43(\mathrm{M}<2.5)$, indicating low strategy use.

\subsection{Levels of foreign language classroom anxiety}

Descriptive statistics (mean value and standard deviation) show that the overall FLA is at a medium level $(\mathrm{M}=102.55$, the score is between +0.67 and -.67 standard deviations from the sample mean) and that all the performance anxieties are also at medium levels (Table 2).

The study reports the highest level of anxiety for communication apprehension $(\mathrm{M}=31.95)$ and the lowest level of anxiety (the highest level of relaxation) for the test anxiety factor $(\mathrm{M}=49.72)$. All the anxiety levels are reported for the communication apprehension, test anxiety, fear of negative evaluation, and overall anxiety among the participants $(15 \leq \mathrm{M} \geq 54,27 \leq \mathrm{M} \geq 65,9 \leq \mathrm{M} \geq 33,52 \leq$ $M \geq 150$, respectively).

Table 2 -Levels of foreign language anxiety

\begin{tabular}{lccc}
\hline \multicolumn{1}{c}{ FLA - factors } & Possible scores & M & SD \\
\hline Communication apprehension & $11-55$ & 31.95 & 7.933 \\
\hline Test anxiety & $15-75$ & 49.72 & 9.741 \\
\hline Fear of negative evaluation & $7-35$ & 20.88 & 6.344 \\
\hline Overall anxiety & $33-165$ & 102.55 & 21.843 \\
\hline
\end{tabular}

$\mathrm{M}$-mean value, SD-standard deviation, $\mathrm{N}$-number of participants

4.3. The effects of students FLCA levels on their speaking strategy use

To determine whether there were significant differences in the students' perceived use of speaking strategies among the high, medium, and low anxiety groups, an analysis of variance (ANOVA) procedure was conducted for the groups' ISSFL scores (Table 3). The respondents representing low, medium, and high levels of anxiety were ascribed to these three categories depending on whether their scores on the FLCAS were in the range 52-86 (18 subjects), 87-118 (27 subjects), and 119150 (15 subjects), respectively.

The results obtained by one-way ANOVA (Table 3) showed there were no statistically significant differences in the overall use of speaking strategies between 
the students manifesting different levels of foreign language anxiety ( $p>0.05)$. However, the results show the differences between the students at different levels of foreign language anxiety in the reported use of the following three speaking strategies: using gestures and using circumlocutions and synonyms when stuck for an English word, and paying attention when someone is speaking in English. The students at the high and low levels of language anxiety reported frequent use of gestures when they cannot think of a word during a conversation in English ( $M=3.75$ and $M=4.00$, respectively, both being $M>3.50$ ); the students at the medium level of language anxiety use this strategy less frequently $(\mathrm{M}=3.39,3.49 \geq$ $\mathrm{M} \geq 2.50$ indicating the medium use) than their peers at high and low anxiety levels $(\mathrm{F}=3.573, \mathrm{p}<0.05, \mathrm{p}=0.035)$. The findings also suggest that students at all levels of FLA use circumlocutions and synonyms when stuck for a word in English. However, this strategy use is significantly higher among the participants at the low level of language anxiety $(\mathrm{M}=4.38)$ than among the participants at the high level of language anxiety $(\mathrm{M}=3.69)(\mathrm{F}=3.219, \mathrm{p}<0.05, \mathrm{p}=0.047)$. The students at the high level of foreign language anxiety are paying attention when someone is speaking in English significantly more frequently $(M=4.74$, indicating a very high strategy use as $\mathrm{M} \geq 4.50)$ than their peers at the low anxiety level $(\mathrm{M}=4.24)(\mathrm{F}=3.393, \mathrm{p}<0.05$, $\mathrm{p}=0.041$ ).

Table 3 -Differences in speaking strategy use dependent on overall FLA

\begin{tabular}{lcccc}
\hline \multirow{2}{*}{\multicolumn{1}{c}{ Speaking strategies }} & \multicolumn{3}{c}{ Levels of overall FLA } & \\
\cline { 2 - 4 } & $\begin{array}{c}\text { high } \\
\text { anxiety } \\
(\mathrm{N}=18)\end{array}$ & $\begin{array}{c}\text { medium } \\
\text { anxiety } \\
(\mathrm{N}=27)\end{array}$ & $\begin{array}{c}\text { low } \\
\text { anxiety } \\
(\mathrm{N}=15)\end{array}$ & $\mathrm{p}$ \\
& $\mathrm{M}$ & $\mathrm{M}$ & $\mathrm{M}$ & \\
\hline Associate new material w/already known & 4.11 & 4.26 & 4.47 & .388 \\
\hline Use new English words in a sentence & 3.00 & 3.22 & 2.87 & .43 \\
\hline $\begin{array}{l}\text { Connect word to a mental picture of the } \\
\text { situation }\end{array}$ & 3.72 & 3.81 & 3.67 & .879 \\
\hline Use rhymes to remember new words & 2.50 & 2.48 & 2.47 & .838 \\
\hline Say new words several times & 3.61 & 3.63 & 3.27 & .595 \\
\hline Try to talk like a native speaker & 3.00 & 3.56 & 3.53 & .137 \\
\hline Practice sounds of English & 3.89 & 3.81 & 3.47 & .489 \\
\hline Start a conversation in English & 2.44 & 2.56 & 3.13 & .101 \\
\hline Make summaries of information & 3.11 & 2.93 & 2.87 & .754 \\
\hline Use gestures when stuck for words & 3.75 & 3.39 & 4.00 & $\mathbf{. 0 3 5}$ \\
\hline Make up new words when stuck & 3.61 & 3.37 & 3.47 & .721 \\
\hline Try to guess what other people will say & 2.78 & 3.04 & 2.73 & .57 \\
\hline Use circumlocutions or synonyms & 3.69 & 3.82 & 4.38 & $\mathbf{. 0 4 7}$ \\
\hline
\end{tabular}




\begin{tabular}{|c|c|c|c|c|}
\hline Notice my mistakes/try to do better & 3.94 & 3.85 & 4.13 & .511 \\
\hline Pay attention when someone is speaking & 4.79 & 4.34 & 4.24 & $.041 *$ \\
\hline Look for people to talk to in English & 3.06 & 3.19 & 3.53 & .206 \\
\hline $\begin{array}{l}\text { Have clear goals for improving speaking } \\
\text { skills }\end{array}$ & 4.61 & 4.52 & 4.47 & .862 \\
\hline $\begin{array}{l}\text { Try to relax when feeling afraid of } \\
\text { speaking }\end{array}$ & 3.83 & 4.26 & 4.47 & 169 \\
\hline $\begin{array}{l}\text { Encourage self to speak when feeling } \\
\text { afraid }\end{array}$ & 3.67 & 4.04 & 4.20 & .262 \\
\hline Give self-reward for doing well & 2.61 & 3.19 & 2.80 & .232 \\
\hline Overall EFL speaking strategies & 3.46 & 3.58 & 3.60 & .654 \\
\hline
\end{tabular}

FLA-foreign language anxiety, $\mathrm{N}$-number of participants, $\mathrm{p}$-statistical significance

\subsection{Discussion}

\subsubsection{Interpretation of results}

The instruments in the study proved to be reliable and internally consistent. The frequent perceived use of English language speaking strategies reported in this study is not consistent with the results of other studies dealing with EFL learners' use of language learning strategies where the students' overall use of language learning strategies was at a medium level $(2.50<\mathrm{M}<3.49)$ (Khalil, 2005; ZhangLiu, 2005; Lee-Oxford, 2008; Yang, 2010). Such a result could be ascribed to various and frequent speaking activities in the ESP classroom (descriptions, presentations, discussions, simulations, negotiations, conflict resolving, role-plays), which allowed the students to use speaking strategies - speaking strategies were neither taught explicitly (they were implicitly embedded in classroom speaking activities) nor awareness-raising training (identifying and assessing through observation, interviews, diaries, or think-aloud protocols) was applied. The findings from ISSFL reveal (Table 1) that the most prominent speaking strategies used by the participants involved: having clear goals for improving speaking skills in English, paying attention when someone is speaking in English, associating new material with what students/learners already know, and trying to relax when feeling afraid of speaking in English. In this study, the students used these strategies more frequently than previous research reported (Liu-Chang, 2013).

The findings also show that the students' language anxiety and its performance anxieties are at a medium level. These results are consistent with the results obtained in the researches studying the language anxiety levels of students learning the English language (Rodrigez-Abreu, 2003; Chiang, 2006; Lucas et al., 2011; Arnaiz-Guillen, 2012). However, there are studies in which high levels of 
language anxiety have been recorded (Gregersen-Horwitz, 2002; Maros-LlinasGaran, 2009). The average score of FLCAS in this study is also lower than that reported by Pawlak (2011) for his university (English Department) students; although such a finding might seem surprising given the fact that biotechnology students are less proficient (B1 level of CEFR, compared to B2-C2 level of CEFR in Pawlak's study) and might be less confident in their language abilities, it can be explained by the fact that they were possibly confronted with lower requirements (due to different proficiency levels) and clear task-oriented instruction characteristic for ESP classrooms (which included frequent speaking activities and their assessment). There is an indication that, besides instructional conditions (e.g. participation in speaking activities in smaller groups) (Young, 1990), classroom atmosphere (e.g. low competition, clear task orientation) is also associated with lower anxiety levels (Palacios, 1998). It should be kept in mind that the value of such comparisons may be limited due to the occurrence of individual variations since the data appear to indicate that the growth in proficiency is accompanied by greater heterogeneity in terms of anxiety levels (Pawlak, 2011). On the other hand, higher levels of relaxations have also been recorded (Pichette, 2009).

Another issue that the study referred to is the differences in speaking strategy use between respondents representing high, medium, and low levels of foreign language anxiety. There has been a paucity of research that touched upon this issue (Pawlak, 2011) as the bulk of research has been correlational (Liu, 2018; Khamkhien, 2012; Pawlak, 2011; Sioson, 2011; Shabani, 2015). The analysis in this study demonstrated that there were differences in overall speaking strategy use between the students manifesting high, medium, and low anxiety - low- and medium-anxious students used speaking strategies frequently $(M=3.60$ and $M=3.58$, respectively), while high-anxious students used speaking strategies at the medium level $(\mathrm{M}=3.46)$, approximating the medium high cut-off point of 3.5 (Oxford, 1990); however, the differences were minute and did not reach statistical significance. These results are similar to the findings in Pawlak's study (2011) in terms of non-existing statistically significant differences in strategy use between high-, medium-, and low-anxious students, though Pawlak reported medium strategy use across the anxiety levels.

However, the differences were found in the frequency of using three individual speaking strategies. Firstly, the medium-anxious students reported significantly less frequent use of gestures when having a problem thinking of a word when speaking in English, which suggests more frequent use of this kinesic element of nonverbal behaviour by high-anxious and low-anxious respondents. 
Based on the findings of the nonverbal behaviour of the participants in a Gregersen's study (2005), it is reasonable to assume that the presence of foreign language anxiety increases self-contact with the body and decreases the use of speech-related gestures. High-anxious learners tend to use gestures less for illustratory and regulatory purposes (which low-anxious students do more frequently) and more for fidgeting and interactionally nonproductive activity. Secondly, those students who showed lower levels of general foreign language anxiety reported using synonyms and circumlocutions when in a problem to find a word (a compensation strategy used frequently among the participants) more frequently than their high-anxious peers. Lowering stress, monitoring one's emotions, and relaxing before speaking in a foreign language learning context enables the learner to a wider variety of words and structures (Pietrzykowska, 2014), even if lacking an appropriate word. Finally, high-anxious students used significantly more frequently a strategy of paying attention when someone is speaking in English than their peers at the lower levels of language anxiety. Learners experiencing higher levels of anxiety might put more effort into paying attention during the language tasks (Chang et al., 2017); a feeling of uneasiness and fear that they will not recognize the words or understand the interlocutor is facilitative enough to make the students alert and attentive.

Although such results suggest that language anxiety levels do not influence the use of speaking strategies, this conclusion might be premature in view of the fact that the students were at the different years of study in the bachelor biotechnology program, with the effect that experience, self-confidence or proficiency (all beyond the scope of this study) could have acted as mediating variables to be reckoned with. Correlation studies, with which the findings of this study are not in line, report the link between strategy use and foreign language anxiety providing the evidence that the high-anxious learners may rely less on strategic devices and vice versa (Liu, 2018; Khamkhien, 2012; Pawlak, 2011; Sioson, 2011; Shabani, 2015).

\subsubsection{Pedagogical implications}

Although the evidence provided by the present study is admittedly tenuous, there still are reasonable grounds (such as the correlational studies previously mentioned) to believe that foreign language anxiety may be an important variable affecting the use of speaking strategies by foreign language learners. While the quantity of speaking strategies used is less important than the students' ability to match them to the task in hand and their learning styles and capably combine them 
with related strategies (Ehrman-Leaver, \& Oxford, 2003), it is reasonable to assume that those learners who shy away from employing speaking strategies will have fewer opportunities even to identify the devices that meet such requirements. It is advisable to pay more attention to the ways of helping students cope with anxiety in the language classroom. Some foreign language anxiety reduction techniques mentioned in the literature involve: the transformation of students' negative self-related cognitions by focusing on positive experiences (MacIntyreGardner, 1991); students verbalizing fears in the classroom through relaxation exercises and journal keeping (Horwitz et al., 1986); making the classroom relaxing and friendly through vocabulary brainstorming activities, language games, pair and group work, role-plays and simulations (Crookall-Oxford, 1991); using affective error correction techniques (Gregersen, 2003); or teachers making the message more interesting or language tests reflecting in-class instruction (Young, 1991).

Understanding the differences between how high-anxious and low-anxious students communicate nonverbally, more precisely whether and how often they use gestures while speaking in a foreign language, will give teachers a starting point for identifying which students are struggling with foreign language anxiety so that the anxiety reduction measures can be taken. When suspicious that nonverbal cues such as using gestures by a student when speaking are indicative of foreign language anxiety, specific techniques discussed previously may prove beneficial in allaying students' anxiety (Gregersen, 2005). Since using synonyms and circumlocutions when lacking an appropriate word when speaking in English can help in interaction, these reducing-anxiety techniques may also be immeasurably helpful in enabling learners at the higher levels of language anxiety not to get blocked and to continue the interaction. Cognitive strategies, such as using synonyms and paraphrasing, enable learners to master vocabulary at such an extent that students find appropriate words more easily, even in a stressful situation (Pietrzykowska, 2014). A certain extent of anxiety might lead to better students' attention to the speaking context (other speakers, potential interlocutors); thus, lowering language anxiety might not always be beneficial for language learning. Instructors, when designing speaking tasks, should consider scaffold or facilitate students who experience high anxiety levels by providing a more authentic or more challenging speaking task that might increase the students' attention (Chang et al., 2017).

\section{CONCLUSION}

The study reported in this paper is one step toward better understanding the use of speaking strategies in the ESP academic context. It reveals that the 
participants used the overall speaking strategies frequently and that foreign language anxiety was at a medium level and individual performance anxieties, i.e. communication apprehension, test anxiety, and fear of negative evaluation, remained at the same medium levels. The quantitative analysis failed to supply evidence for the existence of statistically significant differences in speaking strategy use between the learners characterized by high, medium, and low level of foreign language anxiety, except for three speaking strategies: low-anxious students' more frequent use of synonyms and circumlocutions when they encounter the problem of finding an appropriate word in English than their peers in medium- and highanxious group; high-anxious students paying attention when someone is speaking in English more frequently than medium- and low-anxious students; and mediumanxious students' more frequent use of gestures when they lack the appropriate word in English.

This study has certain limitations. The results consider the perception of academic use of EFL speaking strategies of a limited number of students in a very specific engineering domain. Thus, these results cannot be generalized to the total student population in the biotechnology engineering domain and particularly not to the engineering profession. Also, the instruments applied in the study are self-report scales - it means that the participants' responses depend on their sincerity and willingness to cooperate in the research, and on their awareness of the speaking strategies they use and language anxieties they experience while speaking in English.

The strength of the present study is that it explores the use of speaking strategies at different levels of foreign language anxiety, which has been rarely done by the researchers and mostly with regard to general language learning strategies (Khamkhien, 2012; Pawlak, 2011), and this having been done in English for specific purposes. As many correlation studies suggest (Liu, 2018; Pawlak, 2011; $\mathrm{Wu}, 2010$; Zhang-Liu, 2005) that higher levels of anxiety may go hand in hand with a lower frequency of strategy use, it is reasonable to assume that language anxiety may be an important variable influencing the language strategy use and speaking strategy use in particular. Further research is indispensable in this area, targeting other groups of learners, other methods of investigation, such as interview, diary, observation method, or tapping more specific aspects of anxiety and strategy use (in an ESP context in particular). Future research could also further investigate other learner variables not accounted for by this study such as learning style, gender, age, self-perception, and public speaking activities (e.g. debate). 
Milevica Bojović

\section{STRATEGIJE USMENOG IZRAŽAVANJA I ANKSIOZNOST U UČENJU ENGLESKOG JEZIKA STRUKE U VISOKOŠKOLSKOJ NASTAVI}

\section{Rezime}

Prethodne studije su istakle značaj strategija učenja stranih jezika u ovladavanju jezičkim veštinama (razumevanjem pročitanog teksta, veštinom pisanja i usmenog izražavanja) i da je anksioznost u učenju stranog jezika afektivni faktor koji se često inicira u formalnom obrazovnom kontekstu u učionici. Istraživanja su, takođe, pokazala da učenici koji imaju niži nivo anksioznosti u učenju stranog jezika češće primenjuju strategije učenja stranog jezika od onih učenika koji imaju viši nivo anksioznosti u učenju jezika. Ove karakteristike treba uzeti u obzir prilikom koncipiranja nastave stranog jezika i izrade nastavnog programa učenja stranog jezika. Cilj ovog istraživanja je da ustanovi učestalost primene strategija usmenog izražavanja na engleskom jeziku kao stranom jeziku struke, nivo jezičke anksioznosti kod ispitanika i razlike u upotrebi strategija usmenog izražavanja kod ispitanika na različitim nivoima jezikčke anskioznosti. Ispitano je 60 studenata osnovnih studija, budućih inženjera biotehnologije, koji uče engleski kao strani jezik struke na Univerzitetu u Kragujevcu, Srbija. Instrument korišćen za merenje primene strategija usmenog izražavanja je bila Skala samoprocene učenikovih strategija usmenog izražavanja na stranom jeziku, zasnovana na Skali strategija učenja stranog jezika (Oxford, 1989b). Instrument korišćen za merenje anksioznosti u učenju stranog jezika je bila Skala anksioznosti u učenju stranih jezika (Horwitz, 1986; Horwitz et al., 1986). Rezultati ukazuju na to da su ispitanici često koristili strategije usmenog izražavanja na engleskom jeziku i da su pokazali umeren nivo jezičke anksioznosti u usmenom izražavanju na engleskom jeziku u nastavnoj situaciji. Nisu zabeležene statistički značajne razlike u upotrebi strategija usmenog izražavanja na engleskom jeziku između ispitanika na različitim nivoima anksioznosti. Izuzetak su tri strategije - gestikulacija, korišćenje sinonima i opisnih objašnjenja u nemogućnosti da se sete odgovarajuće reči na engleskom jeziku. Ispitanici koji su imali niži nivo jezičke anksioznosti češće su koristili sinonime i opisna objašnjenja u situacijama kada nisu mogli da se sete adekvatne reči u usmenom izražavanju na engleskom jeziku. Ispitanici koji su bili na višem nivou jezičke anksioznosti češče su obraćali pažnju kada neko govori na engleskom jeziku. U nemogućnosti da se sete odgovarajuće reči na engleskom jeziku češće su gestikulirali ispitanici srednjeg nivoa anksioznosti. Nastavnici stranog jezika bi trebalo da stvaraju pozitivnu atmosferu uz pružanje podrške učenicima i da osposobljavaju učenike da primenjuju strategije usmenog izražavanja. U budućnosti bi trebalo sprovesti istraživanja sa većim brojem ispitanika da bi se potvrdile ovakve tendencije.

Ključne reči: anksioznost, engleski kao jezik struke, strani jezik, usmeno izražavanje, strategije 


\section{REFERENCES}

Aida, Y. (1994). Examination of Horwitz, Horwitz, and Cope's construct of foreign language anxiety: The case of students of Japanese. The Modern Language Journal, 78(2), 155-167. Downloaded 10 May 2010 from http://www.jstor.org/stable/329005. Accessed 10 May 2010.

Arnaiz, P.-Guillen, F. (2012). Foreign language anxiety in a Spanish university setting: Interpersonal differences. Revista de Psicodidactica, 17/1, 5-26.

Chang, H-C.-Fang, W-C.-Yang, B-H.-Luo, B-R.-Chew, S-W. \& Chen, N-S. (2017). Examining the relationships between foreign language anxiety and attention during conversation tasks. In: Popescu, E.-Kinshuk, M.-Khribi, K.-Huang, R.-Jemni, M.-Chen, N-S. \& Sampson, D. J. (Eds.) (2017). Innovations in smart learning. Singapore: Springer Science+Business Media. 1-11.

Cheng, Y.-Horwitz, E. K. \& Schallert, D. L. (1999). Language anxiety: Differentiating writing and speaking components. Language Learning, 49(3), 417-446. doi: 10.1111/0023-8333.00095

Chiang, Y. (2006). Connecting two anxiety constructs: An interdisciplinary study of foreign language anxiety and interpretation anxiety. (Unpublished doctoral dissertation). The University of Texas, Austin (USA). Downloaded 12 September 2019 from http://repositories.lib.utexas.edu/bitstream/handle/2152/2695/chiangd66244 .pdf.

Cohen, A. D. (2005). Strategies for learning and performing L2 speech acts. Intercultural Pragmatics, 2(3), 275-301.

Cohen, A. D. (2010). Focus on the language learner: Style, strategies, and motivation. In: Schmidt, N. (Ed.) (2010). An introduction to applied linguistics. London: Hodder Education, 161-178.

Cohen, A. D. (2014). Strategies in learning and using a second language. New York: Routledge.

Crookall, D.-Oxford, R. L. (1991). Dealing with anxiety: Some practical activities for language learners and teacher trainees. In: Horwitz, E.-Horwitz, I. \& Cope, I. (Eds.) (1991). Language anxiety: From theory and research to classroom implications. Englewood Cliffs, NJ: Prentice Hall. 141-150.

Ehrman, M.-Leaver, B. \& Oxford, R. L. (2003). A brief overview of individual differences in second language learning. System, 31(3), 313-330.

Gkonou, C. (2014). Sociolinguistic parameters of L2 speaking anxiety. In: Pawlak, M.-Bielak, J. and Mystkowska-Wiertelak, A. (Eds.) (2014). Classroom- 
oriented research: Achievements and challenges. Springer International Publishing Switzerland. 15-32.

Goh, C. C. M., \& Burns, A. (2012). Teaching speaking: A holistic approach. Cambridge, England: Cambridge University Press.

Gordon, E. G.-Sarason, S. B. (1955). The relationship between "test anxiety" and "other anxieties". Journal of Personality, 23(3), 317-323. doi: 10.1111/1467-6494.ep8930749.

Gregersen, T. (2003). To err is human: A reminder to teachers of language-anxious students. Foreign Language Annals, 36(1), 25-32.

Gregersen, T. (2005). Nonverbal cues: Clues to the directions of foreign language anxiety. Foreign Language Annals, 38(3), 388-400. doi:10.1111/j.19449720.2005.tb02225.x

Gregersen, T.-Horwitz, E. K. (2002). Language learning and perfectionism: anxious and non-anxious language learners' reactions to their own oral performance. The Modern Language Journal, 86(4), 562-570.

Green, J. M.-Oxford, R. (1995). A closer look at learning strategies, L2 proficiency, and gender. TESOL Quarterly, 29(2), 261-297. doi: $10.2307 / 3587625$

Horwitz, E. K. (1986). Preliminary evidence for the reliability and validity of a Foreign Language Anxiety Scale. TESOL Quarterly, 20, 559-562.

Horwitz, E. K.-Horwitz, M. B. \& Cope, J. (1986). Foreign language classroom anxiety. The Modern Language Journal, 70, 125-132.

Horwitz, E. K. (2010). Research timeline: Foreign and second language anxiety. Language Teaching, 43(2), 154-167. doi:10.1017/S026144480999036X

Huang, X-H.--van Naerssen, M. (1987). Learning strategies for oral communication. Applied Linguistics 8(3), 287-307. doi: https://doi.org/10.1093/applin/8.3.287

Kawai, Y. (2008). Speaking and good language learners. In: Griffiths, C. (ed.) (2008). Lessons from good language learners. Cambridge: Cambridge University Press. 218-230.

Khalil, A. (2005). Assessment of language learning strategies used by Palestinian EFL learners. Foreign Language Annals, 38(1), 108-119. doi:10.1093/applin/8.3.287

Khamkhien, A. (2012). Proficiency, motivation, and classroom anxiety and their effect on language learning strategies used by Thai EFL learners. RJAS, 2(2), 85-98. doi:10.14456/rjas.2012.9 
Lee, K. R.-Oxford, R. (2008). Understanding EFL learners' strategy use and strategy awareness. The Asian EFL Journal, 10(1), 7-32. Downloaded 20 September 2019 from http://www.asian-efljournal.com/March_2008_EBook.pdf

Liu, M. (2018). Interactive effects of English-speaking anxiety and strategy use on oral English test performance of high- and low-proficient Chinese university EFL learners. Cogent Education, 5(1), 1562410. Downloaded 18 June 2020 from https://www.cogentoa.com/article/10.1080/2331186X.2018.1562410

Liu, H.-Chang, C. (2013). A study on language learning strategy use and its relation to academic self-concept: The case of EFL students in Taiwan. Journal of Language Teaching and Research, 4(2), 260-268. doi:10.4304/jltr.4.2.260-268

Lucas, R. I.-Miraflores, E. \& Go, D. (2011). English language learning anxiety among foreign language learners in the Philippines. Philippine ESL Journal, 7, 94-119.

Maros-Llinas, M.-Garan, M. J. (2009). Effects of language anxiety on three proficiency-level courses of Spanish as a foreign language. Foreign Language Annals, 42(1), 94-111.

MacIntyre, P. D. (1999). Language anxiety: A review of the research for language teachers. In: Young, D. J. (Ed.) (1999). Affect in foreign language and second language teaching: A practical guide to creating a low-anxiety classroom atmosphere. Boston: Mc Graw-Hill. 24-45.

MacIntyre, P. D.-Gardner, R. C. (1991). Investigating language class anxiety using the focused essay technique. The Modern Language Journal, 75(3), 296304.

MacIntyre, P. D.-Gardner, R. C. (1994). The subtle effects of language anxiety on cognitive processing in the second language. Language Learning, 44, 283305.

MacIntyre, P. D.-Noels, K. A. (1996). Using social-psychological variables to predict the use of language learning strategies. Foreign Language Annals, 29(3), 373- 386.

Murray, B. (2010). Students' language learning strategy use and achievement in the Korean as a foreign language classroom. Foreign Language Annals, 43(4), 624-634. doi:10.1111/j.1944-9720.2010.01105.x

Oh, J. (1992). Learning strategies used by university EFL students in Korea. Language Teaching [Korea], 1, 3-53. 
Ohata, K. (2005). Potential sources of anxiety for Japanese learners of English: Preliminary case interviews with five Japanese college students in the U.S. TESL-EJ, 9(3), 1-21.

Olivares-Cuhat, G. (2010). Relative importance of learning variables on L2 performance. Linguistik online, 43(3/10), 99-116. Downloaded 11 September 2019 from http://www.linguistikonline.de/43_10/olivarescuhat.pdf

O'Malley, J. M.-Chamot, A. U. (1990). Learning strategies in second language acquisition. Cambridge: Cambridge University Press.

O’Malley, J. M.-Chamot, A. U.-Stewner-Manzanares, G.-Russo, R. P. \& Kupper, L. (1985). Learning strategy applications with students of English as a second language. TESOL Quarterly, 19(3), 557-584. doi:10.2307/3586278

Oxford, R. L. (1989). Strategy Inventory for Language Learning. Downloaded 30 July 2019 from http://www.finchpark.com/arts/sille.doc

Oxford, R. L. (1990). Language learning strategies: What every teacher should know. New York: Newbury House.

Oxford, R. L. (2017). Teaching and researching language learning strategies: Selfregulation in context. New York and London: Routledge.

Palacios, L. M. (1998). Foreign language anxiety and classroom environment: A study of Spanish university students. $\mathrm{PhD}$ dissertation, Austin, The University of Texas.

Pawlak, M. (2011). Anxiety as a factor influencing the use of language learning strategies. In: Pawlak, M. (Ed.) (2011). Extending the boundaries of research of second language learning and teaching. Berlin-Heideleberg: Springer Verlag. 149-165.

Pawlak, M. (2018a). Grammar learning strategy inventory (GLSI): Another look. Studies in Second Language Learning and Teaching, 8(2), 351-379. doi: 10.14746/ssllt.2018.8.2.8

Pawlak, M. (2018b). Investigating the use of speaking strategies in the performance of two communicative tasks: The importance of communicative goal. Studies in the Second Language Learning and Teaching 8(2), 269-291. See doi: 10.14746/ssllt.2018.8.2.5

Pietrzykowska, A. (2014). The relationship between learning strategies and speaking performance. In: Pawlak, M.-Mystkowska-Wiertelak, A. \& Bielak, J. (Eds.) (2014). Classroom-oriented research: Achievements and challenges. Heidelberg: Springer. 55-68. 
Pichette, F. (2009). Second language anxiety and distance language learning. Foreign Language Annals, 42(1), 77-93.

Rodriguez, M.-Abreu, O. 2003. The stability of general foreign language classroom anxiety across English and French. The Modern Language Journal, 87(3), 365-374.

Rubin, J. (1975). What the "good language learner" can teach us? TESOL Quarterly, 9(1), 41-51.

Samimy, K. K. (1994). Teaching Japanese: Considerations of learners' affective variables. Theory into Practice, 33(1), 29-33. Downloaded 3 October 2019 from http://www.jstor.org/stable/1476413?origin=JSTOR-pdf.

Shabani, M. B. (2015). On the relationship between foreign language anxiety and language learning strategies among Iranian EFL learners. International Journal of Educational Investigations, 2(2), 9-23.

Sioson, I. C. (2011). Language learning strategies, beliefs, and anxiety in academic speaking task. Philippine ESL Journal, 7, 3-27.

Sparks, R. L.-Ganschow, L. (2007). Is the foreign language classroom anxiety scale measuring anxiety or language skills? Foreign Language Annals, 40(2), 260-287. doi: 10.1111/j.1944-9720.2007.tb03201.x

Stern, H. H. (1975). What can we learn from the good language learner? Canadian Modern Language Review, 31(4), 304-18.

Tallon, M. (2011). Heritage speakers of Spanish and foreign language anxiety: A pilot study. Texas Papers in Foreign Language Education, 15(1), 70-87. $\begin{array}{lllll}\text { Downloaded } & 10 & \text { February } & 2013 & \text { from }\end{array}$ http://studentorgs.utexas.edu/flesa/TPFLE_New/Index.htm.

Toth, Z. (2008). A foreign language anxiety scale for Hungarian learners of English. WoPaLP, 2, 55-78. Downloaded 23 December 2011 from http://langped.elte.hu/WoPaLParticles/W2TothZs.pdf.

Tudor, I. (1996). Learner-centredness as Language Education. Cambridge: Cambridge University Press.

Watson, D.-Friend, R. (1969). Measurement in social-evaluative anxiety. Journal of Consulting and Clinical Psychology, 33(4), 448-457.

$\mathrm{Wu}$, Kun-huei. (2010). The relationship between language learners' anxiety and learning strategy in the CLT classroom. International Education Studies. 3(1), 174-191.

Yamashiro, A. D.-McLaughlin, J. (2001). Relationships among attitudes, motivation, anxiety, and English language proficiency in Japanese college students. In: Robinson, P.-Sawyer, M. \& Ross, S. (eds.) (2001). Second 
language acquisition research in Japan: JALT Applied Materials Series, Vol. 4. Tokyo, Japan: Japan Association of Language Teachers Press. 1933.

Yan, J. X.-Horwitz, E. K. (2008). Learner's perceptions of how anxiety interacts with personal and instructional factors to influence their achievement in English: A qualitative analysis of EFL learners in China. Language Learning, 58(1), 151-181. doi: 10.1111/j.1467-9922.2007.00437.x

Yang, M. (2010). Language learning strategies of English as a foreign language university students in Korea. (Unpublished doctoral dissertation). The College of Graduate and Professional Studies Department of Curriculum, Instruction, and Media Technology, Indiana State University. Downloaded 11 September 2019 from http://scholars.indstate.edu/handle/10484/968?mode=full

Yang, N. D. (1999). The relationship between EFL learners' beliefs and learning strategy use. System, 27(4), 515-535. doi:10.1016/S0346-251X(99)00048-2

Young, D. J. (1990). An investigation of students' perspectives on anxiety and speaking. Foreign Language Annals, 23(6), 539-553. doi: 10.1111/j.19449720.1990.tb00424.x

Young, D. J. (1991). Creating a low anxiety classroom environment: What does language anxiety research suggest? The Modern Language Journal, 75, 426-439.

Young, D. J. (1999). Affect in foreign language and second language learning: A practical guide to creating a low-anxiety classroom atmosphere. Boston: McGraw-Hill.

Zhang, X.-Liu, Y. (2005). Language learning strategies and language achievement: Across-cultural study. CELEA Journal, 28(3), 82-89. Downloaded 28 September 2019 from http://www.celea.org.cn/teic/61/61-82.pdf 